\title{
Comparative Winter Bioenergetics of American Bison, Yak, Scottish Highland nad Hereford Calves
}

\author{
R. J. CHRISTOPHERSON, R. J. HUDSON \& R. J. RICHMOND
}

Christopherson R. J., Hudson R. J. \& Richmond R. J., 1978: Comparative winter bioenergetics of American bison, yak, Scottish Highland and Hereford calves. Acta theriol., 23, 2: 49-54 [With 3 Tables].

American bison, yak, Scottish Highland and Hereford calves were used in a comparative study of metabolic responses to temperature of 20,0 and $-30^{\circ} \mathrm{C}$. Metabolic rates were lowest in the bison, highest in the Herefords and intermediate in the Highland and yak. Critical temperatures and thermal insulations as calculated from metabolic responses to three ambient temperatures suggested that the bison were most tolerant to cold and that the Herefords were least tolerant. Highland and yak were intermediate and comparable in this regard.

[Dept. Animal Sci., Univ. Alberta, Edmonton, Canada T6G 2E3].

\section{INTRODUCTION}

A large proportion of Northern and Western Canada is consiclered marginal for traditional systems of agricultural production. However, growing human populations in these areas have created increasing demands for agricultural commodities, particularly animal products. Although intensive production techniques permit livestock to be raised in very harsh environments, input costs are prohibitive. This has lead to an evaluation of alternative animal species which could make more efficient use of such areas and, in particular, survive the long harsh winters with minimal care.

American bison (Bison bison), yak (Bos grunniens) and Scottish Highland cattle (Bos taurus) have relatively deep and dense hair coats and are considered to be quite cold tolerant (Peters \& Sle n, 1964). Although a number of breeds of cattle have been studied (W e bs t e r, 1971; Webster et al., 1970) there is no quantitative data on the metabolic responses of bison and yak during cold exposure. The objectiwes of this study were to compare feed intakes, metabolic rates, thermal insulations and lower critical temperatures of bison, yak, Scottish Highland and Hereford calves during winter. 


\section{EXPERIMENTAL}

A total of eight calves including two yak, two American bison, two Scottish Highland and two Hereford were kept in outdoor pens with access to an open southfacing shed. Except for one young bull bison, all animals were heifers. They were obtained and assembled into groups in early November at about 5 months of age and were trained for use in metabolic trials for two months prior to the three month experimental period.

The calves were offered a ration consisting of 50 percent chopped alfalfabrome hay and 50 percent concentrate at a rate of $100 \mathrm{~g} / \mathrm{kg} .75 / \mathrm{day}$. Each $100 \mathrm{~kg}$ of concentrate contained $91 \mathrm{~kg}$ barley, $6 \mathrm{~kg}$ rapeseed meal, $2 \mathrm{~kg}$ cobalt-iodized salt, $0.6 \mathrm{~kg}$ dicalcium phosphate and $0.4 \mathrm{~kg}$ vitamin A premix.

The calves were confined in individual feeding stalls overnight from approximately 16.30 hours to 09.30 hours for provision of the daily ration. Feed intake of individual animals was recorded daily and liveweight was measured at weekly intervals.

Measurements were made of the metabolic rate of each calf during late January, February and March while exposed to experimental temperatures of $+20,0$ and $-30^{\circ} \mathrm{C}$. Metabolic rates were measured during the 2nd or 3rd hour of exposure to each temperature using a custom-designed closed circuit indirect calorimeter. Oxygen consumption and carbon dioxide production were measured in a sealed refridgerated chamber of known volume which was periodically flushed with atmospheric air. The concentrations of oxygen and carbon dioxide in the chamber were measured using the respiratory pattern analyzer described by Young et al. (1975). Heat production ( $H p)$ was calculated from respiratory gas exchange using the equation of B rouwer (1965):

$$
\left.\mathrm{Hp}(\mathrm{kcal} / \mathrm{hr})=\mathrm{O}_{2}\left(\text { litres.h-1) }{ }^{-1}\right) \times 3.866+\mathrm{CO}_{2} \text { (litres. }{ }^{-1}\right) \times 1.200
$$

Total thermal insulations and lower critical temperatures were estimated from the extent of the metabolic responses to cold. Total thermal insulation $(I)$ was calculated from the following equation:

$$
I=(T b-T a) / H n
$$

where $\mathrm{Tb}=$ body core temperature $\left({ }^{\circ} \mathrm{C}\right)$

$\mathrm{T} a=$ air temperature $\left({ }^{\circ} \mathrm{C}\right)$

$H n=$ sensible heat loss (Mcal.M-2.24 $\mathrm{h}^{-1}$ )

$I=$ thermal insulation (C.Mcal-1. $\mathrm{M}^{2} .24 \mathrm{~h}$ ).

Equation 1 is an oversimplification since it neglects the resistance to tissue conduction of the heat that is lost by evaporation from the surface of the skin and respiratory passages.

Sensible heat loss $(\mathrm{Hn})$ was estimated from the following relationship:

$$
H p \pm H s=H l=H n+H e
$$

where $H p=$ rate of heat production

$\mathrm{Hl}=$ rate of total heat loss

$H e=$ rate of evaporative heat loss

$H s=$ rate of body heat storage per unit time.

At temperatures below the thermoneutral zone, $\mathrm{He}$ was assumed to be constant with a value of 0.3 Mcal.M-2.24 $\mathrm{h}^{-1}$ (W e bster, 1971) and changes in body heat storage $(\mathrm{Hs})$ were assumed to be negligible during the periods when measu- 
rements of heat production were made. Hence for the present application equation (2) was simplified as follows:

$$
H p=H n+0.3
$$

The estimations of $\mathrm{Hn}$ from $\mathrm{Hp}$ measured during exposure of the calves to $-30^{\circ} \mathrm{C}$ were then substituted in equation (1) in order to calculate total insulation (I).

Lower critical temperature (Tac) was calculated from the following equation described by W e b ster (1971):

$$
T a c=(T b+0.3 I e)-H P *(I t+I e)
$$

where $T b=$ body core temperature

$$
I e=\text { external insulation }
$$

$I t=$ tissue insulation

$\mathrm{Hp}^{*}=$ rate of heat production in a thermoneutral environment.

Tissue insulation (It) was estimated according to the following equation (W e b s t e r, 1971):

$$
I t=5.50+0.018 W+0.099 T a
$$

where $W=$ body weight $(\mathrm{kg})$

$\mathrm{T} a=$ air temperature below $0^{\circ} \mathrm{C}$.

External insulation (Ie) was calculated by subtracting tissue insilation from total insulation:

$$
I e=I-I t
$$

\section{RESULTS AND DISCUSSION}

In spite of the small sample sizes, significant $(P<.01)$ contrasts were found among species in feed intake, weight change and bioenergetic characteristics. Average daily feed intakes and body weight changes are summarized in Table 1. Hereford calves consumed their entire daily ration whereas Highland, yak and bison calves did not consume their entire feed allocation. The yak had the lowest daily feed intake on a metabolic weight basis $\left(\mathrm{kg}^{\cdot 75}\right)$ followed by bison, Highland and finally Hereford in order of increasing voluntary consumption. This pattern paralleled results of a previous study ( $\mathrm{R}$ ichmond et al., 1977). Average daily gains reflected species-typical feed intakes ranging from only $0.112 \mathrm{~kg} \cdot \mathrm{d}^{-1}$ in the yak to $0.710 \mathrm{~kg} \cdot \mathrm{d}^{-1}$ in the Herefords. Since the average feed intake of the yak was only slightly above maintenance and weight gains were small, their feed:gain ratio was poor. These ratios were more favorable for the Highland, Hereford and bison. Bison and Highland were comparable with only slightly lower feed:gain ratios than the Hereford.

The metabolic rates of the calves are summarized in Table 2. Energy expenditures over the complete range of experimental conditions generally were lowest in the bison, highest in the Herefords and interme- 
diate in the Highland and the yak. Values in all species were higher in March than in January and February.

Metabolic responses to cold from which thermal insulations and critical temperatures were calculated, differed markedly among each of the bovids. Metabolic rates of Highland, Hereford and yak increased during exposure to $-30^{\circ} \mathrm{C}$ compared to metabolic rates at $0^{\circ} \mathrm{C}$ and $20^{\circ} \mathrm{C}$ indi-

Table 1

Feed intake, initial weight, average daily gain and feed/gain ratios for a 96 day winter feeding period.

\begin{tabular}{|c|c|c|c|c|c|}
\hline & \multicolumn{2}{|c|}{ Feed intake ${ }^{1}$} & \multirow{2}{*}{$\begin{array}{c}\text { Initial } \\
\text { weight } \\
\text { kg }\end{array}$} & \multirow{2}{*}{$\begin{array}{c}\text { Average } \\
\text { daily gain } \\
\text { kg/day }\end{array}$} & \multirow{2}{*}{$\begin{array}{c}\text { Feed/gain } \\
\text { ratio }\end{array}$} \\
\hline & $\mathrm{gm} / \mathrm{kg} \cdot 75 /$ day & $\mathrm{kg} /$ day & & & \\
\hline Yak & 65 & 2.34 & 110.9 & 0.112 & 20.9 \\
\hline Bison & 81 & 3.25 & 117.9 & 0.421 & 7.71 \\
\hline Hereford & 100 & 5.07 & 157.8 & 0.710 & 7.14 \\
\hline Highland & 92 & 4.51 & 152.8 & 0.615 & 7.62 \\
\hline
\end{tabular}

1 Species differences significant at $P<0.001$

Table 2

Metabolic rate (kcal/kg.75/day) of calves during winter ${ }^{1}$.

\begin{tabular}{lrccc}
\hline Species & Temp., ${ }^{\circ} \mathrm{C}$ & Jan. & Feb. & March \\
\hline Yak & 20 & 128.2 & 111.7 & 143.5 \\
& 0 & 123.4 & 137.2 & 164.2 \\
Bison & -30 & 146.2 & 150.1 & 181.8 \\
& 20 & 118.2 & 105.3 & 160.4 \\
Hereford & 0 & 117.9 & 124.0 & 168.6 \\
& -30 & 90.7 & 104.6 & 135.4 \\
Highland & 20 & 138.7 & 141.8 & 155.7 \\
& 0 & 146.5 & 152.0 & 174.2 \\
Mean monthly & -30 & 186.2 & 186.1 & 259.8 \\
temperature, ${ }^{\circ} \mathrm{C}$ & 20 & 109.0 & 116.6 & 132.9 \\
& 0 & 127.9 & 133.7 & 144.7 \\
& -30 & 137.4 & 136.8 & 171.3 \\
& & -10.2 & -8.5 & -5.6 \\
& & $(-42.0 \text { to } 7.8)^{2}$ & $(-29$ to 10$)$ & $(-34$ to 11$)$ \\
\hline
\end{tabular}

1 Species and date significant at $P<.01$

2 Values in parenthesis indicate range of temperatures.

cating that $-30^{\circ} \mathrm{C}$ was below their lower critical temperatures. One of the most striking observations was the qualitatively different response of bison to intense cold. Whereas the other species increased metabolic rates to offset heat loss, the bison reduced metabolic rates during all periods of exposure to temperatures of $-30^{\circ} \mathrm{C}$. It can be speculated that the major adapiive significance of this characteristic may be the reduction of expenditure of energy reserves at a time when cold stress 
and food deprivation are superimposed. The bison may use thermal inertia to deal with cold in a manner similar to that used by the camel or eland to combat periodic heat loads ( $\mathrm{T}$ a y $\mathrm{l}$ o r, 1975).

In order to calculate thermal insulation values (equation 1), estimates of heat loss must be made while the animals are exposed to an environmental temperature below their lower critical temperature. Since the bison calves were not below their critical temperature even at $-30^{\circ} \mathrm{C}$ it was not possible to determine their true insulation values. Therefore, estimates of total insulation which were considered minimal were made for the bison. Insulation values (Table 3 ) were lowest for the Herefords, highest for the bison and intermediate for yak and Highland. Insulation values for all animals were highest in January

Table 3

Thermoneutral heat production and estimates of total insulation and lower critical temperature of calves during winter.

\begin{tabular}{|c|c|c|c|c|}
\hline & & January & February & March \\
\hline Total insulation & Yak & 32.2 & 31.4 & 26.6 \\
\hline \multirow[t]{3}{*}{ C.m.24 hr/Mcal * } & Bison & $>59.1$ & $>46.7$ & $>33.5$ \\
\hline & Hereford & 24.5 & 23.2 & 16.2 \\
\hline & Highland & 35.4 & 33.7 & 27.6 \\
\hline Heat production & Yak & 2.11 & 1.84 & 2.38 \\
\hline \multirow[t]{3}{*}{$\mathrm{Mcal} / \mathrm{m}^{2} / 24 \mathrm{hr}^{*}$} & Bison & 1.97 & 1.77 & 2.72 \\
\hline & Hereford & 2.37 & 2.44 & 2.70 \\
\hline & Highland & 1.86 & 2.00 & 2.31 \\
\hline \multirow{4}{*}{ Lower critical temp. ${ }^{\circ} \mathrm{C}$} & Yak & -16 & -11 & -17 \\
\hline & Bison & $<-40$ & $<-30$ & $<-40$ \\
\hline & Hereford & -12 & -14 & -3 \\
\hline & Highland & -16 & -20 & -14 \\
\hline
\end{tabular}

* $\mathrm{m}^{2}=$ surface area (square meters) was calculated from the following formula: $\mathrm{m}^{2}=0.09 \mathrm{~W} \cdot 67$, where $W=$ boò weight in $\mathrm{kg}$ (M i t chell, 1928).

and February with a sharp decline in March. The estimates of the lower critical temperatures of the four groups of bovids are summarized in Table 3.

Experimental findings agreed with what/is known about the ecology of each species. The range of the bison in North America extends into relatively inhospitable climates characterized by long seiges of intense cold. The yak lives in cold mountainous environments but is able to migrate seasonally to seek favorable microclimates. The Highland breed was selected for damp cool environments whereas the Hereford was selected in areas with more moderate winter conditions. 


\section{REFERENCES}

1. Brouwer E., 1965: Report of subcomittee on constants and factors. [In: »Energy Metabolism«], Publ. Europ. Ass. Anim. Prod. No. 11: 1-441.

2. Mitchell H. H., 1928: Livestock investigations. Univ. Illinois. Agric. Exp. Sta. Ann. Rept. 155.

3. Richmond R. J., Hudson R. J., Christopherson R. J., 1977: Comparison of forage intake and digestibility by American bison, yak and cattle. Acta theriol., 22: 225-230.

4. Peters H. F. \& Slen S. B., 1964: Hair coat characteristics of Bison, Domestic $\times$ Bison Hybrids, Cattalo and certain Domestic Breeds of beef cattle. Can. J. Animal Sci. 44: 48-57.

5. T a y 1 or C. R., 1975: Temperature regulation and water requirements of desert mammals: physiological strategies and constraints of domestication. [In: $» P h y-$ siological Adaptations to the Environment«, F. J. Vernberg, ed.]. Intext Educational Publ., New York.

6. We bster A. J. F., 1971: Prediction of heat losses from cattle exposed to cold outdoor environments. J. Appl. Physiol. 30: 684-690.

7. Webster A. J. F., Chumlecky J. \& Young B. A., 1970: Effects of cold environments on the energy exchanges of young beef cattle. Can. J. Anim. Sci. 50: 89-100.

8. Young B. A., Kerrigan B. \& Christopherson R. J., 1975: A versatile respiratory pattern analyzer for studies of energy metabolism of livestock. Can. J. Anim. Sci. 55: 17-22.

Accepted, August 15, 1977.

CHRISTOPHERSON R. J., HUDSON R. J. i RICHMOND R. J.

ZIMOWE ZAPOTRZEBOWANIE ENERGETYCZNE U BIZONA, JAKA I DWU RAS BYDEA

\section{Streszczenie}

Przeprowadzono porównawcze badania nad zapotrzebowaniem energetycznym u bizona, jaka oraz bydła (ras - Scottish Highland i Hereford) w temperaturach 20,0 i $-30^{\circ} \mathrm{C}$ (Tabela 1). Tempo metabolizmu było najniższe $u$ bizona, najwyższe u bydła rasy Hereford, a pośrednie u jaka i bydła rasy Scottish Highland (Tabela 2). Obliczono zakres temperatur krytycznych i termiczną izolacyjność, co pozwoliło stwierdzić, że najbardziej odporne na działanie chłodu są bizony a najmniej bydło rasy Hereford, natomiast dwie pozostałe grupy zwierząt wykazują właściwości pośrednie (Tabela 3). 